\title{
IDENTIFIKASI KOMODITI UNGGULAN PADA SEKTOR PERTANIAN DI KABUPATEN INDRAGIRI HILIR PROVINSI RIAU
}

\author{
${ }^{1)}$ Sisca Vaulina dan Khairizal \\ ${ }^{1)}$ Staff Pengajar Fakultas Pertanian Universitas Islam Riau Pekanbaru \\ Email: Sisca_vaulina@yahoo.com
}

\begin{abstract}
ABSTRAK
Setelah otonomi masing-masing daerah memiliki lebih dari kebebasan dalam menentukan komoditas yang diprioritaskan dalam pembangunannya. Salah satu potensi di Kabupaten Indragiri Hilir adalah pertanian. Untuk pertanian diperlukan identifikasi komoditas pertanian utama yang akan dikembangkan. Tujuan dari penelitian ini adalah mengidentifikasi komoditas pertanian utama terlihat dari dasar komoditas pertanian, spesialisasi dan lokalisasi komoditas pertanian yang diprioritaskan untuk dikembangkan di Kabupaten Indragiri Hilir. Penelitian menggunakan metode studi kasus, data yang digunakan adalah data dari tahun 2014-2015, menggunakan analisis ekonomi LQ regional, spesialisasi quotient dan lokalisasi quotient. Hasil penelitian menunjukkan komoditas di Kabupaten Indragiri Hilir kering padi, kacang tanah, ubi kayu, pepaya, durian, mangga, kelapa, pinang, kelapa, sagu, domba, sapi dan perikanan umum. KS dan KL nilai kegiatan pertanian terspesialisasi di setiap kabupaten. Pengembangan prioritas komoditas padi kering, kedelai, kacang tanah, ubi kayu, pepaya, mangga, durian, jeruk, pinang, kakao, domba dan perikanan umum.
\end{abstract}

Kata kunci : Komoditas Unggulan, Komoditas Pertanian

\section{PENDAHULUAN}

Undang-Undang RI No.32 Tahun 2004 tentang Pemerintah Daerah dan Undang-Undang RI No.33 Tahun 2004 tentang Perimbangan Keuangan Pusat dan Daerah telah merubah paradigma daerah dalam penyelenggaraan pemerintahan dari pola sentralistik ke pola desentralistik. Paradigma ini menuntut daerah agar mampu mengatur pemerintahannya guna tercapai pembangunan daerah terutama di sektor pertanian.

Setelah otonomi daerah, masing-masing daerah sudah lebih bebas dalam menetapkan komoditi unggulan agar diprioritaskan pengembangannya. Farahmand (2011), pertumbuhan kota atau daerah dipengaruhi oleh faktor-faktor yang berbeda. Sjahrizal (1997), keberhasilan perencanaan pembangunan di suatu daerah sangat berkaitan dengan kualitas perencanaan pembangunan yang disusun oleh daerah tersebut. Perbedaan kondisi daerah akan membawa implikasi bahwa corak pembangunan yang diterapkan berbeda pula. Terkait dengan potensi pembangunan yang dimiliki setiap daerah sangat bervariasi, maka setiap daerah

42 Identifikasi Komoditi Unggulan Pada Sektor Pertanian Di Kabupaten Indragiri Hilir Provinsi Riau 
harus menentukan kegiatan sektor ekonomi yang dominan. Pertanian merupakan urat nadi perekonomian di Kabupaten Indragiri Hilir. BPS Kabupaten Indragiri Hilir (2013), sebagian besar wilayah Kabupaten Indragiri Hilir (80\%) memiliki struktur tanah yang berupa tanah Orgonosol (Histosol), yaitu tanah gambut yang banyak mengandung bahan organik. Disamping itu, sebagian wilayah di kabupaten ini juga merupakan daerah yang memiliki dataran yang berbeda antara lain: (1) daerah dataran rendah, (2) daerah dataran rendah pesisir, dan (3) daerah datar sampai berombak. Suhu harian rata-rata $27^{\circ} \mathrm{C}$ dan suhu maksimum dapat mencapai $33^{\circ} \mathrm{C}$ dan dari segi suhu tidak ada masalah untuk kehidupan dan untuk tanaman pertanian.

Di kabupaten Indragiri Hilir, sektor pertanian memiliki keunggulan dan prospek yang lebih baik untuk dikembangkan dan diharapkan dapat mendorong sektor-sektor lain untuk berkembang. BPS Propinsi Riau (2013), sumbangan sektor-sektor PDRB Kabupaten Indragiri Hilir pada kurun waktu 2003-2012 didominasi oleh tiga sektor yaitu sektor pertanian $(43,72 \%)$, sektor perdagangan, hotel dan restoran $(17,73 \%)$ dan sektor industri pengolahan $(17,68 \%)$.

Informasi mengenai komoditi pertanian yang menjadi unggulan dan penyebarannya akan membantu dan memudahkan pemerintah dalam pengambilan kebijakan-kebijakan di bidang pertanian. Tujuan penelitian ini untuk mengidentifikasi komoditas pertanian unggulan yang dilihat dari komoditas basis pertanian; spesialisasi dan lokalisasi komoditas basis pertanian yang diprioritaskan untuk dikembangkan di Kabupaten Indragiri Hilir.

\section{METODE PENELITIAN}

Metode penelitian menggunakan metode studi kasus. Yin (1984), metode penelitian studi kasus sebagai penyelidikan yang menyelidiki fenomena dalam konteks kehidupan nyata. Satuan kasus pada penelitian ini yakni komoditi unggulan di Kabupaten Indragiri Hilir. Daerah penelitian ditentukan secara sengaja di Kabupaten Indragiri Hilir, dengan pertimbangan selain kelengkapan data; kabupaten ini merupakan daerah yang sektor pertaniannya memberikan kontribusi terbesar dalam perekonomian wilayah. Data yang digunakan dalam penelitian ini adalah data sekunder berupa data time series tahun 2014-2015 yakni data produksi sektor pertanian (subsektor tanaman bahan makanan; subsektor perkebunan; subsektor 
peternakan; dan subsektor perikanan) yang diperoleh dari BPS Kabupaten Indragiri Hilir, BPS Propinsi Riau.

\section{Rancangan Analisis}

1. Location Quotient (LQ) digunakan untuk melihat basis wilayah komoditi.

Formulasinya:

$$
\begin{aligned}
L Q=\frac{S_{i} / S}{N_{i} / N} & \text { atau LQ } \\
= & \frac{S_{i} / N_{i}}{S / N} \ldots . .
\end{aligned}
$$

(Isard, 1960)

Keterangan :

$\mathrm{S}_{\mathrm{i}} \quad$ : Jumlah produksi komoditi pertanian di kecamatan- $i$

$\mathrm{S} \quad$ : Jumlah produksi komoditi pertanian di kabupaten Indragiri Hilir

$\mathrm{N}_{\mathrm{i}} \quad$ : Jumlah total produksi komoditi pertanian di kecamatan- $i$

$\mathrm{N} \quad$ : Jumlah total produksi komoditi pertanian di kabupaten Indragiri Hilir

Kriteria pengambilan keputusan:

LQ $>1$ : Komoditi pertanian merupakan sektor basis

LQ $<1$ : Komoditi pertanian merupakan sektor non basis

LQ $=1$ : Komoditi pertanian telah mampu mencukupi kebutuhan kecamatan

Location Quotient (LQ) merupakan alat analisis yang digunakan oleh ahli ekonomi regional untuk memperkirakan kegiatan basis dan nonbasis dari sektor ekonomi (Fadali and Harris, 2006). Asumsi metode LQ ini adalah penduduk di wilayah yang bersangkutan mempunyai pola permintaan setiap kecamatan sama dengan pola permintaan kabupaten. Asumsi lainnya adalah bahwa permintaan wilayah akan sesuatu barang akan dipenuhi terlebih dahulu oleh produksi wilayah, kekurangannya diimpor dari wilayah lain (Budiharsono, 2001). LQ juga menunjukkan efisiensi relatif wilayah, serta terfokus pada substitusi impor yang potensial atau produk dengan potensi ekspansi ekspor. Hal ini akan memberikan suatu gambaran tentang industri mana yang terkonsentrasi dan industri mana yang tersebar (Shukla, 2000).

2. a. Kuosien Spesialisasi $(\mathrm{KS} / \beta)$ digunakan untuk melihat spesialisasi wilayah komoditi. Formulasinya:

$\mathrm{KS}=\{(\mathrm{Si} / \Sigma \mathrm{Si})-(\mathrm{Ni} / \Sigma \mathrm{Ni})\}$

Keterangan:

$\mathrm{KS}=$ Kuosien Spesialisasi

$\mathrm{Si}=$ Produksi komoditi pertanian di wilayah kecamatan- $i$

$\mathrm{Ni}=$ Produksi komoditi pertanian di kabupaten Indragiri Hilir

44 Identifikasi Komoditi Unggulan Pada Sektor Pertanian Di Kabupaten Indragiri Hilir Provinsi Riau 
$\Sigma \mathrm{Si}=$ Total produksi komoditi pertanian di kecamatan- $i$

$\Sigma \mathrm{Ni}=$ Total produksi komoditi pertanian di kabupaten Indragiri Hilir

Kriteria pengambilan keputusan:

$\beta \geq 1$ : Komoditi pertanian terspesialisasi pada suatu kecamatan- $i$

$\beta<1$ : Komoditi pertanian tidak terspesialisasi dibeberapa wilayah di kecamatan- $i$

b. Kuosien Lokalisasi (KL/ $\alpha$ ) digunakan untuk mengukur penyebaran (konsentrasi) relatif/lokalisasi pengembangan komoditi di suatu wilayah. Formulasinya:

$\mathrm{KL}=\{(\mathrm{Si} / \mathrm{Ni})-(\Sigma \mathrm{Si} / \Sigma \mathrm{Ni})\}$

Keterangan:

$\mathrm{KL} \quad=$ Kuosien Lokalisasi

$\mathrm{Si}=$ Produksi komoditipertanian di wilayah kecamatan- $i$

$\mathrm{Ni} \quad=$ Produksi komoditi di kabupaten Indragiri Hilir

$\Sigma \mathrm{Si}=$ Total produksi komoditipertanian di kecamatan- $i$

$\Sigma \mathrm{Ni}=$ Total produksi komoditi di kabupaten Kabupaten Indragiri Hilir

Kriteria pengambilan keputusan:

$\alpha \geq 1$ :Komoditipertanian terkonsentrasi pada suatu kecamatan- $i$

$\alpha<1$ :Komoditipertanian tersebar di beberapa wilayah di kecamatan- $i$

3. Prioritas pengembangan komoditi pertanian unggulan.

Penentuan komoditi yang menjadi prioritas untuk dikembangkan digunakan nilai LQ terbesar dari komoditi pertanian pada tiap kecamatan, kemudian dilihat nilai KS $(\beta)$.Jika nilai spesialisasinya paling tinggi dari komoditi yang ada berarti komoditi tersebut mempunyai keunggulan komparatif untuk diproduksi di kecamatan tersebut.

\section{HASIL DAN PEMBAHASAN}

\section{Identifikasi Komoditi Unggulan Sektor Pertanian di Kabupaten Indragiri Hilir}

Rustiadi, dkk (2011) adanya sistem perwilayahan komoditas diharapkan dapat meningkatkan efisiensi sistem produksi dan distribusi komoditas, karena perwilayahan komoditas pada dasarnya adalah suatu upaya memaksimalkan “comparative advantage" setiap wilayah. Hayami dan Ruttan (1971), pengembangan wilayah mau tidak mau memang memanfaatkan sejumlah sumber daya alam.

Komoditi basis pertanian masing-masing kecamatan di Kabupaten Indragiri Hilir dapat dilihat pada Tabel 5. Jumlah komoditi basis pertanian 
berbeda-beda untuk setiap kecamatan.Kecamatan Reteh, kecamatan Enok dan kecamatan Tempuling mempunyai komoditi basis pertanian yang paling banyak yaitu 16 komoditi. Sementara itu, kecamatan yang mempunyai komoditi basis pertanian paling sedikit adalah kecamatan Kuala Indragiri, kecamatan Concong dan kecamatan Gaung dengan 8 komoditi.

Komoditi basis pertanian merupakan komoditi yang memiliki keunggulan dan berperan dalam meningkatkan pendapatan wilayah dari sektor pertanian. Christofakis and Gkouzos (2013), memanfaatkan produksi dari sektor pertanian mampu memaksimalkan ekonomi dan manfaat sosial pada tiap wilayah.

Pengembangan komoditi basis akan meningkatkan pendapatan dari komoditi non basis pertanian serta sektor-sektor ekonomi lainnya dalam perekonomian Kabupaten Indragiri Hilir. Komoditi basis pertanian di Kabupaten Indragiri Hilir dapat dilihat pada Tabel 5.

Tabel 5. Komoditi Basis Pertanian Berdasarkan Kecamatan di Kabupaten Indragiri Hilir, Tahun 2015

\begin{tabular}{|c|c|c|c|}
\hline No & Kecamatan & $\begin{array}{c}\text { Jumlah } \\
\text { Komoditi }\end{array}$ & Komoditi Basis Pertanian \\
\hline 1 & Keritang & 12 & $\begin{array}{l}\text { Padi sawah, cabai merah, mangga, jeruk, pisang, pepaya, pinang, } \\
\text { kelapa sawit, sapi, domba, itik, perikanan umum. }\end{array}$ \\
\hline 2 & Kemuning & 13 & $\begin{array}{l}\text { Padi ladang, jagung, kedelai, ubi kayu, ubi jalar, cabai merah, pisang, } \\
\text { pepaya, kelapa sawit, karet, sapi, kambing, perikanan umum. }\end{array}$ \\
\hline 3 & Reteh & 16 & $\begin{array}{l}\text { Padi sawah, kedelai, kacang hijau, ubi jalar, cabai merah, mangga, } \\
\text { jeruk, pepaya, pinang, kopi, kelapa dalam, nipah, kambing, domba, } \\
\text { itik, perikanan laut. }\end{array}$ \\
\hline 4 & Sungai Batang & 15 & $\begin{array}{l}\text { Padi sawah, kacang hijau, cabai merah, mangga, jeruk, pisang, } \\
\text { pepaya, pinang, kakao, kopi, kelapa dalam, sapi, domba, itik, } \\
\text { perikanan laut. }\end{array}$ \\
\hline 5 & Enok & 16 & $\begin{array}{l}\text { Jagung, kedelai, kacang tanah, kacang hijau, ubi kayu, ubi jalar, cabai } \\
\text { merah, durian, jeruk, pepaya, kelapa dalam, nipah, kambing, domba, } \\
\text { itik, perikanan umum. }\end{array}$ \\
\hline 6 & Tanah Merah & 11 & $\begin{array}{l}\text { Jagung, kacang tanah, ubi kayu, ubi jalar, cabai merah, pisang, kelapa } \\
\text { dalam, nipah, kambing, itik, perikanan umum. }\end{array}$ \\
\hline 7 & $\begin{array}{l}\text { Kuala } \\
\text { Indragiri }\end{array}$ & 8 & $\begin{array}{l}\text { Padi sawah, pisang, pepaya, kelapa dalam, kambing, ayam pedaging, } \\
\text { itik, perikanan laut. }\end{array}$ \\
\hline 8 & Concong & 8 & $\begin{array}{l}\text { Ubi kayu, mangga, pisang, kelapa dalam, sapi, kambing, itik, } \\
\text { perikanan laut. }\end{array}$ \\
\hline 9 & Tembilahan & 10 & $\begin{array}{l}\text { Padi sawah, ubi kayu, petsai, mangga, jeruk, pisang, pepaya, kelapa } \\
\text { dalam, ayam pedaging, perikanan umum. }\end{array}$ \\
\hline 10 & $\begin{array}{l}\text { Tembilahan } \\
\text { Hulu }\end{array}$ & 11 & $\begin{array}{l}\text { Padi sawah, mangga, pisang, pepaya, pinang, kakao, kopi, kelapa } \\
\text { dalam, kelapa hibrida, ayam pedaging, perikanan umum. } \\
\text { Jagung, kacang tanah, kacang hijau, ubi kayu, ubi jalar, cabai merah, }\end{array}$ \\
\hline 11 & Tempuling & 16 & $\begin{array}{l}\text { pepaya, nanas, pinang, kakao, kopi, kelapa hibrida, karet, sapi, } \\
\text { kambing, perikanan umum. }\end{array}$ \\
\hline 12 & Kempas & 14 & $\begin{array}{l}\text { Jagung, kedelai, cabai merah, pepaya, nanas, pinang, kakao, kopi, } \\
\text { kelapa hibrida, kelapa sawit, karet, sapi, kambing, perikanan umum. }\end{array}$ \\
\hline 13 & $\begin{array}{l}\text { Batang Tuaka } \\
\text { Gaung Anak }\end{array}$ & 12 & $\begin{array}{l}\text { Padi sawah, jagung, mangga, jeruk, pisang, pepaya, pinang, kelapa } \\
\text { sawit, sapi, domba, itik, perikanan umum. }\end{array}$ \\
\hline
\end{tabular}




\begin{tabular}{|c|c|c|c|}
\hline 14 & Serka & 13 & Padi sawah, petsai, mangga, durian, jeruk, pisang, pepaya, pinang, \\
\hline 15 & Gaung & 8 & $\begin{array}{l}\text { sagu, kelapa dalam, sapi, kambing, perikanan umum. } \\
\text { Padi sawah, pisang, pinang, sagu, kelapa dalam, sapi, itik, perikanan }\end{array}$ \\
\hline 16 & Mandah & 13 & $\begin{array}{l}\text { Jagung, ubi kayu, ubi jalar, cabai merah, durian, pisang, pepaya, sagu, } \\
\text { kelapa dalam, sapi, kambing, itik, perikanan laut. }\end{array}$ \\
\hline 17 & Kateman & 9 & $\begin{array}{l}\text { Jagung, kacang tanah, ubi kayu, ubi jalar, petsai, nanas, kelapa dalam, } \\
\text { kambing, perikanan laut. }\end{array}$ \\
\hline 18 & Pelangiran & 13 & $\begin{array}{l}\text { Jagung, ubi kayu, ubi jalar, cabai merah, mangga, jeruk, pisang, sagu, } \\
\text { kelapa hibrida, sapi, kambing, domba, perikanan umum. }\end{array}$ \\
\hline 19 & $\begin{array}{l}\text { Teluk } \\
\text { Belengkong }\end{array}$ & 13 & $\begin{array}{l}\text { Jagung, kacang tanah, kacang hijau, ubi kayu, ubi jalar, petsai, } \\
\text { mangga, nanas, kopi, kelapa hibrida, domba, itik, perikanan umum. }\end{array}$ \\
\hline 20 & & 12 & $\begin{array}{l}\text { Jagung, kacang tanah, kacang hijau, ubi kayu, ubi jalar, petsai, nanas, } \\
\text { kelapa hibrida, sapi, domba, itik, perikanan umum. }\end{array}$ \\
\hline
\end{tabular}

Berdasarkan Tabel 5, komoditi yang layak untuk dikembangkan bagi pembangunan di Kabupaten Indragiri Hilir tahun 2016, yakni;

1. Komoditi subsektor tanaman pangan, terdiri dari padi ladang; kacang tanah; ubi kayu; pepaya; durian; mangga.

2. Komoditi subsektor perkebunan, terdiri dari nipah; pinang; kelapa; kelapa sawit; sagu.

3. Komoditi subsektor peternakan, terdiri dari domba dan sapi.

4. Subsektor perikanan terdiri dari perikanan umum.

Senada dengan penelitian Vaulina (2013), subsektor tanaman bahan makanan, subsektor perkebunan dan subsektor perikanan merupakan sektor basis dan memiliki peran penting dalam perekonomian di Kabupaten Indragiri Hilir. Glasson (1974) semakin banyak sektor basis dalam suatu wilayah akan menambah arus pendapatan ke wilayah tersebut, menambah permintaan terhadap barang dan jasa di dalamnya, dan menimbulkan kenaikan volume sektor non basis.

\section{Spesialisasi dan Lokalisasi Komoditi Pertanian di Kabupaten Indragiri Hilir}

\section{A. Kuosien Spesialisasi (KS)}

Penggunaan analisis KS untuk mengetahui adanya spesialisasi terhadap komoditi pertanian ditingkat kecamatan atau ditingkat kabupaten. Tabel 6 menunjukkan Kabupaten Indragiri Hilir tidak memiliki capaian indeks spesialisasi yang memiliki nilai koefisien spesialisasi di atas 1, artinya bahwa setiap komoditi di kabupaten ini tidak terspesialisasi dan memiliki keunggulan komparatif yang rendah untuk kegiatan pertanian dalam memproduksi komoditas tertentu.Secara rinci dapat dilihat pada Tabel 6. 
Pada Tabel 6, capaian indeks spesialisasi terendah adalah komoditi kakao dengan nilai 0,004 sedangkan yang tertinggi adalah komoditi ubi kayu 0,970. Jagung $(0,870)$, perikanan umum $(0,860)$ dan jeruk $(0,810)$ memiliki nilai indeks spesialisasi hampir mendekati 1, ini artinya bahwa komoditi tersebut di Kabupaten Indragiri Hilir hampir menjadi komoditi spesial di wilayah ini.

Tabel 6. Nilai Kuosien Spesialisasi Tiap Komoditi Pertanian di Kabupaten Indragiri Hilir, Tahun 2015

\begin{tabular}{clcclc}
\hline No & \multicolumn{1}{c}{ Komoditi } & Kuosien Spesialisasi & No & \multicolumn{1}{c}{ Komoditi } & $\begin{array}{c}\text { Kuosien } \\
\text { Spesialisasi }\end{array}$ \\
\hline 1. & Padi sawah & 0,050 & 17. & Kelapa Hibrida & 0,470 \\
2. & Padi ladang & 0,490 & 18. & Kelapa Dalam & 0,510 \\
3. & Jagung & 0,870 & 19. & Kelapa Sawit & 0,580 \\
4. & Kedelai & 0,020 & 20. & Pinang & 0,200 \\
5. & Kacang tanah & 0,020 & 21. & Kakao & 0,004 \\
6. & Kacang hijau & 0,030 & 22. & Sagu & 0,120 \\
7. & Ubi kayu & 0,970 & 23. & Kopi & 0,002 \\
8. & Ubi jalar & 0,190 & 24. & Karet & 0,030 \\
9. & Cabai merah & 0,370 & 25. & Nipah & 0,200 \\
10. & Petsai & 0,630 & 26. & Sapi & 0,340 \\
11. & Nanas & 0,380 & 27. & Domba & 0,060 \\
12. & Mangga & 0,430 & 28. & Itik & 0,440 \\
13. & Durian & 0,003 & 29. & Kambing & 0,560 \\
14. & Jeruk & 0,810 & 30. & Ayam Pedaging & 0,470 \\
15. & Pisang & 0,620 & 31. & Perikanan Umum & 0,860 \\
16. & Pepaya & 0,310 & 32. & Perikanan Laut & 0,140 \\
\hline
\end{tabular}

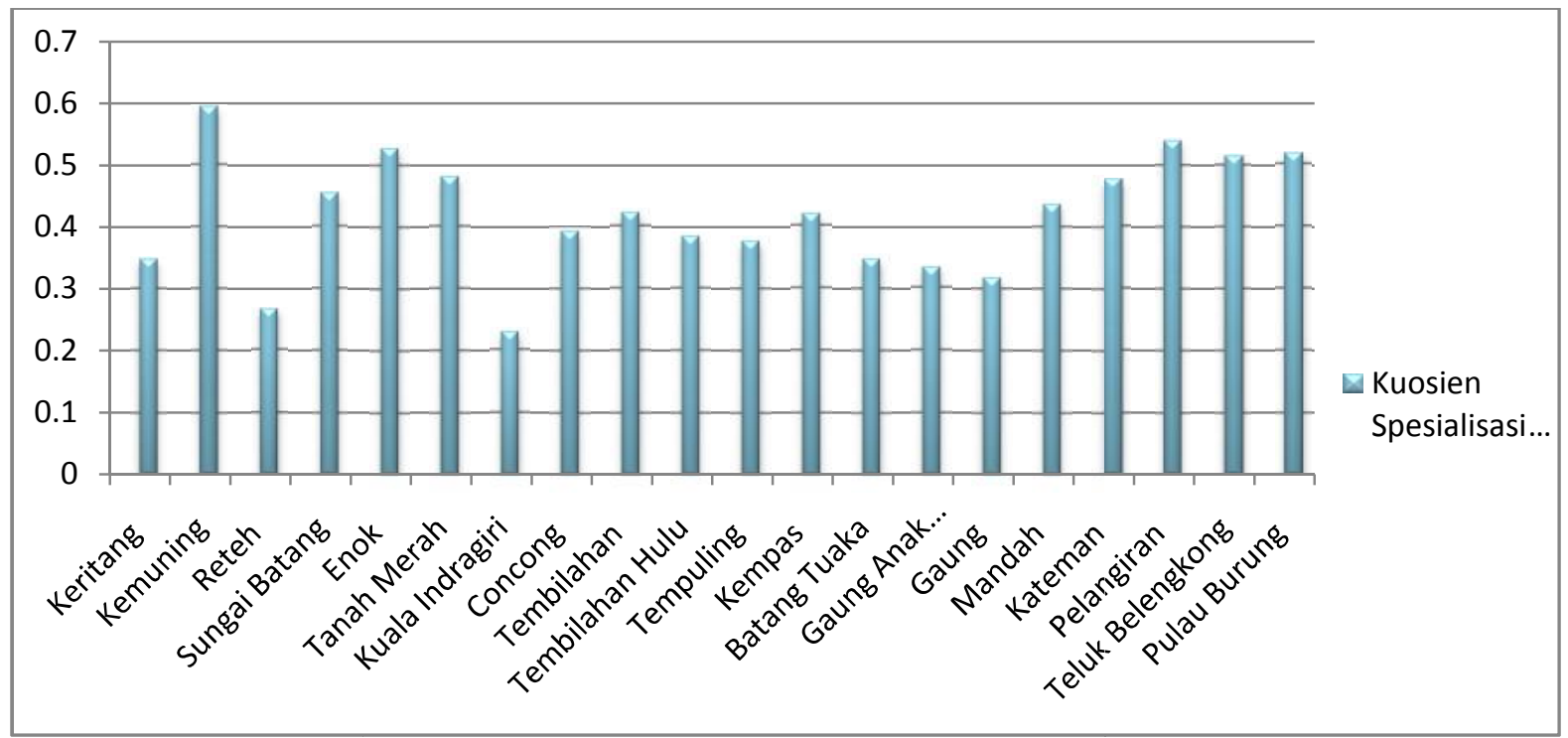

Gambar1.Nilai Kuosien Spesialisasi di Kabupaten Indragiri Hilir, Tahun 2015

Nilai KS untuk tiap-tiap kecamatan di Kabupaten Indragiri Hilir kurang dari satu (Gambar 1). Hal ini menunjukkan bahwa tidak ada spesialisasi kegiatan pertanian terhadap komoditi tertentu di setiap kecamatan. Nilai KS yang positif menunjukkan bahwa suatu kecamatan mempunyai keunggulan komparatif untuk 
memproduksi komoditi pertanian. Kecamatan Kemuning merupakan kecamatan yang mempunyai nilai KS tertinggi $(0,593)$. Hal ini berarti bahwa Kecamatan Kemuning memiliki efisiensi yang relatif tinggi dalam memproduksi komoditi pertanian sehingga pengembangan komoditi pertanian untuk kepentingan ekspor ke wilayah lain sangat menguntungkan kecamatan tersebut. Sementara itu, nilai KS yang terendah terdapat di Kecamatan Kuala Indragiri (0,228). Salah satu rendahnya nilai KS pada kecamatan ini karena keadaan geografis di kecamatan ini memiliki dataran rendah pesisir serta berbatasan langsung dengan adanya pasang surut air laut.

Secara keseluruhan, Kabupaten Indragiri Hilir mempunyai nilai KS ratarata sebesar 0,418, artinya kabupaten initidak ada spesialisasi terhadap kegiatan pertanian sehingga tidak terspesialisasi pada komoditi pertanian tertentu. Potensi yang dimiliki oleh suatu wilayah akan mempengaruhi kegiatan perekonomian. Dengan adanya perbedaan potensi tersebut, masyarakat dan pemerintah daerah mampu mengenali potensi yang dimiliki daerahnya.

\section{B. Kuosien Lokalisasi (KL)}

Analisis kuosien lokalisasi digunakan untuk mengetahui tingkat penyebaran kegiatan pertanian di kecamatan atau di kabupaten. Selain itu, KL juga digunakan untuk mengetahui potensi kegiatan pertanian sehingga dapat diperkirakan lokasi yang memiliki potensi untuk pengembangan komoditi pertanian tertentu dan potensi kegiatan pertanian disuatu kecamatan.

KL komoditi pertanian di Kabupaten Indragiri Hilir menyebar sangat merata dan tingkat lokalisasi setiap komoditi pertanian bervariasi. Berdasarkan Tabel 7, indeks KL di Kabupaten Indragiri Hilir berkisar antara 0,009 sampai dengan 0,98, dengan capaian terendah adalah komoditi padi sawah sedangkan yang tertinggi adalah komoditi padi ladang. Ini mengindikasikan bahwa untuk tanaman pangan di Kabupaten Indragiri Hilir, komoditi padi sawah merupakan komoditi tanaman pangan yang paling menyebar pada wilayah-wilayah kecamatan, sedangkan komoditi padi ladang merupakan komoditi yang terkonsentrasi pada kecamatan tertentu yakni Kecamatan Kemuning. Nilai KL dapat dilihat pada Tabel 7. 
Tabel 7. Nilai Kuosien Lokalisasi Tiap Komoditi Pertanian di Kabupaten Indragiri Hilir, Tahun 2015

\begin{tabular}{|c|c|c|c|c|c|}
\hline No & Komoditi & $\begin{array}{l}\text { Kuosien } \\
\text { Lokalisasi }\end{array}$ & No & Komoditi & $\begin{array}{c}\text { Kuosien } \\
\text { Lokalisasi }\end{array}$ \\
\hline 1. & Padi sawah & 0,009 & 17. & Kelapa Hibrida & 0,23 \\
\hline 2. & Padi ladang & 0,98 & 18. & Kelapa Dalam & 0,05 \\
\hline 3. & Jagung & 0,12 & 19. & Kelapa Sawit & 0,28 \\
\hline 4. & Kedelai & 0,22 & 20. & Pinang & 0,26 \\
\hline 5. & Kacang tanah & 0,18 & 21. & Kakao & 0,42 \\
\hline 6. & Kacang hijau & 0,30 & 22. & Sagu & 0,32 \\
\hline 7. & Ubi kayu & 0,13 & 23. & Kopi & 0,19 \\
\hline 8. & Ubi jalar & 0,13 & 24. & Karet & 0,29 \\
\hline 9. & Cabai merah & 0,09 & 25. & Nipah & 0,81 \\
\hline 10. & Petsai & 0,13 & 26. & Sapi & 0,19 \\
\hline 11. & Nanas & 0,28 & 27. & Domba & 0,19 \\
\hline 12. & Mangga & 0,36 & 28. & Itik & 0,07 \\
\hline 13. & Durian & 0,39 & 29. & Kambing & 0,09 \\
\hline 14. & Jeruk & 0,52 & 30. & Ayam Pedaging & 0,26 \\
\hline 15. & Pisang & 0,41 & 31. & Perikanan Umum & 0,18 \\
\hline 16. & Pepaya & 0,15 & 32. & Perikanan Laut & 0,03 \\
\hline
\end{tabular}

Jika dilihat berdasarkan kecamatan, semua kecamatan yang ada di Kabupaten Indragiri Hilir tidak terkonsentrasi pada komoditi tertentu (Gambar 2). Kecamatan yang memiliki nilai KL tertinggi yakni Kecamatan Kemuning (KL 0,343) sedangkan terendah yakni Kecamatan Kuala Indragiri (KL 0,007). Kecamatan Kemuning merupakan salah satu kecamatan yang memiliki komoditi pertanian unggulan terbanyak yaitu 13 komoditi, terutama untuk komoditi padi ladang. Sementara itu, untuk Kecamatan Kuala Indragiri memiliki komoditi pertanian unggulan paling sedikit yaitu 8 komoditi.

Secara keseluruhan, dapat diketahui bahwa semua kecamatan di Kabupaten Indragiri Hilir tidak terkonsentrasi pada komoditi tertentu (komoditi tersebar di setiap kecamatan) dengan nilai KL rata-rata 0,149. Penyebaran komoditi pertanian dapat bermanfaat untuk memperkirakan lokasi yang potensial untuk komoditi tertentu sehingga dapat mempermudah pemerintah daerah dalam mengembangkan komoditi pertanian tersebut. 


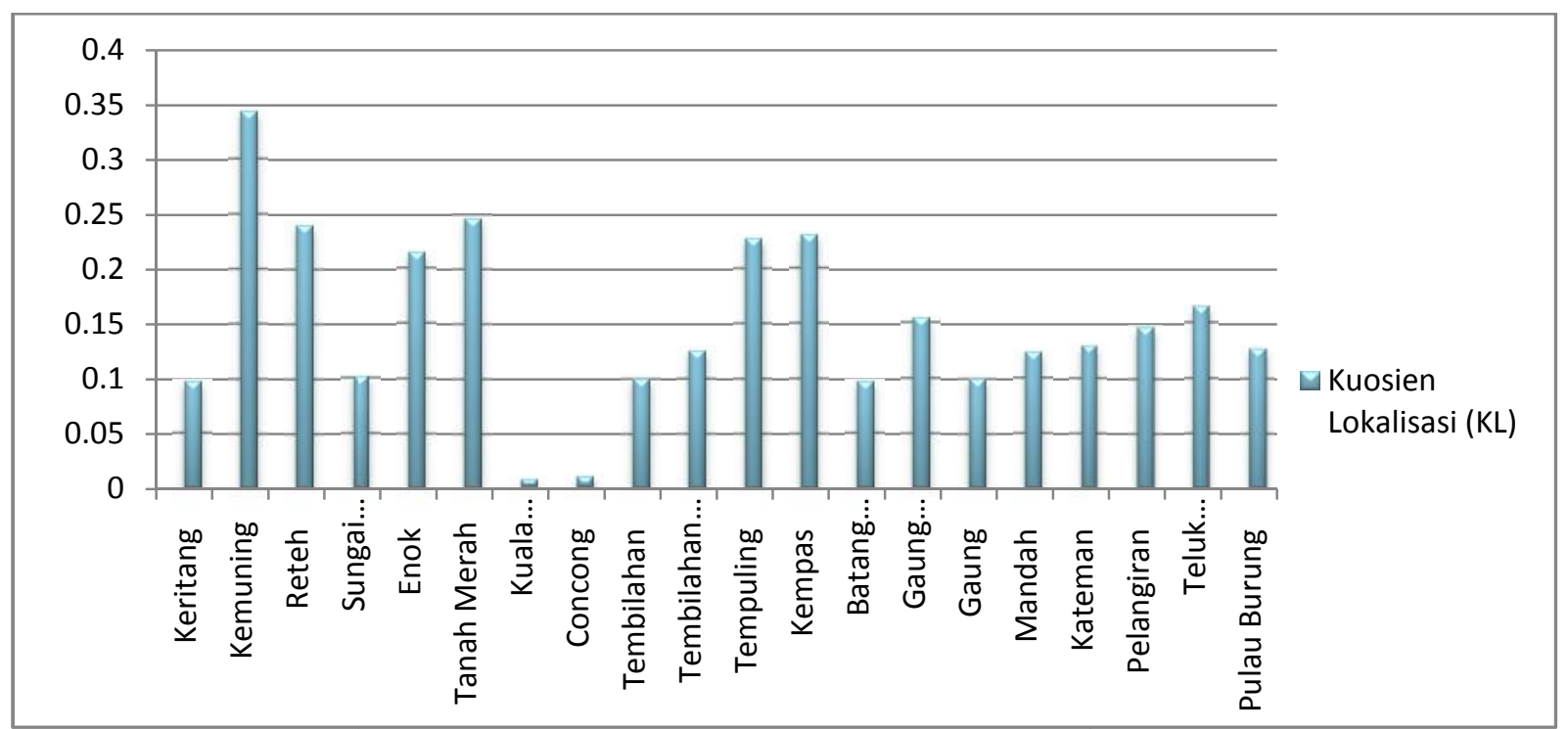

Gambar 2.Nilai Kuosien Lokalisasi di Kabupaten Indragiri Hilir, Tahun 2016

\section{Prioritas Pengembangan Komoditi Unggulan}

Prioritas pengembangan komoditipertanian unggulan di Kabupaten Indragiri Hilir yang dapat dilihat dari nilai LQ tertinggi dari komoditi pertanian tiap kecamatan dan nilai KS tertinggi dari tiap kecamatan. Hal ini berarti bahwa suatu komoditi memiliki keunggulan komparatif untuk diproduksi secara lebih efisien di kecamatan dan diprioritaskan pengembangannya ditingkat kabupaten. Prioritas komoditi pertanian unggulan untuk dikembangkan ditiap kecamatan di Kabupaten Indragiri Hilir.

Diketahui komoditi pertanian unggulan yang menjadi prioritas untuk dikembangkan di setiap kecamatan di Kabupaten Indragiri Hilir yaitu:

1. Subsektor Tanaman Bahan Makanan: Padi ladang (Kec.Kemuning), Kedelai (Kec.Enok), Kacang tanah (Kec.Tanah Merah, Kec.Kateman, Kec.Teluk Belengkong, Kec.Pulau Burung), Ubi kayu (Kec.Concong), Pepaya (Kec.Keritang, Kec.Kuala Indragiri, Kec.Tempuling, Kec.Batang Tuaka), Mangga (Kec.Reteh, Kec.Tembilahan Hulu), Durian (Kec. Gaung Anak Serka, Kec.Mandah), Jeruk (Kec Tembilahan).

2. Subsektor Perkebunan: Pinang (Kec. Sungai Batang) dan Kakao (Kec. Kempas)

3. Subsektor Peternakan: Domba (Kec. Pelangiran)

4. Subsektor Perikanan: Perikanan Umum (Kec. Gaung)

51 Identifikasi Komoditi Unggulan Pada Sektor Pertanian Di Kabupaten Indragiri Hilir Provinsi Riau 
Komoditi pertanian yang diunggulkan Pemda Kabupaten Indragiri Hilir yakni padi, kedelai dan jagung. Kabupaten Indragiri Hilir dijadikan sebagai sentral pangan di Provinsi Riau maupun nasional. Kabupaten Indragiri Hilir memiliki potensi yang besar menjadi sumber pangan bagi Provinsi Riau (Riau Mandiri, 2015). Dengan demikian terdapat persamaan komoditi yang diunggulkan Pemerintah Daerah Kabupaten Indragiri Hilir dengan hasil penelitian yaitu pada komoditi padi dan kedelai. Komoditi jagung menjadi komoditi unggulan dikarenakan kabupaten ini merupakan salah satu sentra penghasil jagung. Selain itu, komoditi jagung terspesialisasi pada 10 kecamatan di Kabupaten Indragiri Hilir.

Potensi lahan basah (pasang surut) untuk persawahan di Kabupaten Indragiri Hilir seluas \pm 57.642 ha dan yang belum dimanfaatkan seluas \pm 23.965 ha, potensi pengembangan lahan kering seluas \pm 169.000 ha dan yang belum dimanfaatkan seluas \pm 84.648 ha. Disamping itu, potensi lahan yang dapat dikembangkan untuk usaha ternak seluas \pm 225.863 ha dengan daya tampung \pm 902.452 ekor yang dipergunakan untuk ternak besar dan ternak kecil. Dengan potensi lahan yang tersedia, prioritas komoditi unggulan dapat dikembangkan. Dengan demikian diharapkan pemahaman potensi dapat dijadikan sebagai dasar perencanaan pembangunan daerah sehingga diharapkan mampu meningkatkan pendapatan daerah.

Pada subsektor perikanan, program kerja pembangunan perikanan di Kabupaten Indragiri Hilir telah mengacu pada 4 (empat) usaha pokok, yaitu intensifikasi, ekstensifikasi, diversifikasi, dan rehabilitasi serta terus meningkatkan peranan perusahaan swasta dalam dunia perikanan dalam rangka pemerataan dan peningkatan pendapatan nelayan/petani ikan melalui peningkatan produksi dan produktifitas usaha, memenuhi kebutuhan konsumen ikan dalam negeri, penyediaan bahan baku industri dan peningkatan ekspor. Mora and Juan (2004), peningkatan spesialisasi wilayah dikhususkan untuk daerah yang memiliki produk yang berorientasi ekspor.

\section{KESIMPULAN}

1. Komoditi unggulan di Kabupaten Indragiri hilir dengan nilai LQ > 1 yaitu komoditi padi ladang, kacang tanah, ubi kayu, pepaya, durian, mangga, nipah, pinang, kelapa, sagu, domba, sapi dan perikanan umum. 
2. Nilai KS tertinggi yakni komoditi ubi kayu $(0,970)$ dan terendah komoditi kakao (0,004). Secara keseluruhan, nilai KS tertinggi di Kecamatan Kemuning $(0,593)$ dan terendah di Kecamatan Kuala Indragiri $(0,228)$. Disamping itu, nilai KL tertinggi yakni komoditi padi ladang $(0,98)$ dan terendah komoditi padi sawah $(0,009)$. Secara keseluruhan, nilai KL tertinggi juga terdapat di Kecamatan Kemuning $(0,343)$ dan nilai KL terendah di Kecamatan Kuala Indragiri $(0,007)$.

3. Prioritas pengembangan komoditi unggulan yakni komoditi padi ladang, kedelai, kacang tanah, ubi kayu, pepaya, mangga, durian, jeruk, pinang, kakao, domba, dan perikanan umum.

\section{DAFTAR PUSTAKA}

Badan Pusat Statistik. 2013. Indragiri Hilir dalam Angka. Tembilahan.

- 2015. Indragiri Hilir dalam Angka. Tembilahan.

- 2013. Pendapatan Regional Kabupaten/Kota Se-Propinsi Riau Menurut Lapangan Usaha 2003-2012. Pekanbaru.

Budiharsono, S. 2001. Teknik Analisis Pembangunan Wilayah Pesisir dan Lautan. Pustaka Sains dan Teknologi. Pradnya Paramita, Jakarta.

Christofakis, M., Gkouzos, Andreas. 2013. Regional Specialisation And Efficiency Of The Agricultural Sector In Greece: The Relationship With Regional Funding Allocation. Regional And Sectoral Economic Studies, Vol. 13 (1); 199-130

Fadali, E. Thomas R. Harris. 2006. Estimated Economic Impacts of The Cattle Ranching and Farming Sector on The Elko County Economy. Technical Report Uced 2005/06-26. University of Nevada, Reno.

Farahmand, S., Nematollah Akbari and Mina Abootalebi. 2012. Spatial Effects of Localization and Urbanization Economies On Urban Employment Growth in Iran. Journal of Geography and Regional Planning Vol. 5 (4), pp. 115121.

Glasson, J. 1974. An Introduction to Regional Planning. The Built Environment. Hutchinson \& Co (Publishers) Ltd. Fitzroy Square, London.

Hayami, Y and V.W. Ruttan. 1971. Agricultural Development; an International Perspective. The Johns Hopleins Press. Baltimore and London. 
Isard, W. 1960. Methods of Regional Analysis : An Introduction to Regional Science. The M.I.T. PRESS. Massachusetts Institute of Technology. Cambridge, Massachusetts, and London, England.

Mora, R. and San Juan,C. 2004. Geographical Specialisation in Spanish Agriculture Before and After Integration in the European Union. Regional Science and Urban Economics, 34 (3): 309-320

Rodjak, A. 2005. Manajemen Usahatani. Pustaka Giratuna, Bandung.

Rustiadi, E. Sunsun Saefulhakim. Dyah R. Panuju. 2011. Perencanaan dan Pengembangan Wilayah. Crestpent Press dan Yayasan Pustaka Obor Indonesia, Jakarta.

Satari, G., Tati, N., Oih, A. A. M., Aep, W. I., Agus, W. 2005. Dasar-Dasar Agronomi. Pustaka Giratuna, Bandung.

Shukla, A. 2000. Regional Planning and Sustainable Development. Kanisha Pub. New Delhi, 291 pp.

Sjafrizal. 1997. Pertumbuhan Ekonomi dan Ketimpangan Regional Wilayah Indonesia Bagian Barat. Prisma; LP3ES, Jakarta.

Soekarni, M. 2006. Analisa Kebijakan Pengembangan Ekonomi Daerah di Kabupaten Indragiri Hilir. Tembilahan.

Vaulina, S. 2013. Peran Sektor Pertanian dalam Perekonomian Kabupaten Indragiri Hilir Propinsi Riau. Jurnal Dinamika Pertanian, Vol XXVIII (3); 245-254.

Warpani.1984. Analisis Kota dan Daerah. Penerbit ITB, Bandung.

Www. Riau mandiri.com. 2015.Kementerian Pertanian Lakukan Evaluasi Musim Tanam di Kabupaten Indragiri Hilir. [diakses pada 31 Oktober 2015].

Yin, R. K. 1984. Case Study Research: Design and Methods. Newbury Park, Sage, CA.

54 Identifikasi Komoditi Unggulan Pada Sektor Pertanian Di Kabupaten Indragiri Hilir Provinsi Riau 